Munroe, W. A., Lewis, C. A., Jr. \& Dunlap, R. B. (1978) Biochem. Biophys. Res. Commun. 80, 355-360

Polgár, L. (1975) Eur. J. Biochem. 51, 63-71

Segal, H. L. \& Boyer, P. D. (1953) J. Biol. Chem. 204, 265-281

Shames, S. L. \& Byers, L. D. (1981a) J. Am. Chem. Soc. 103, 6170-6177

Shames, S. L. \& Byers, L. D. (1981b) J. Am. Chem. Soc. 103, 6177-6184

Soukri, A., Mougin, A., Corbier, C., Wonacott, A., Branlant, C. \& Branlant, G. (1989) Biochemistry 28, 2586-2592

Sparkes, M. J. \& Dixon, H. B. F. (1991) Biochem. J. 275, 772-773

Stallcup, W. B. \& Koshland, D. E., Jr. (1973a) J. Mol. Biol. 80, 41-62
Stallcup, W. B. \& Koshland, D. E., Jr. (1973b) J. Mol. Biol. 80, 63-76 Stallcup, W. B. \& Koshland, D. E., Jr. (1973c) J. Mol. Biol. 80, 77-91

Stallcup, W. B., Mockrin, S. C. \& Koshland, D. E., Jr. (1972) J. Biol. Chem. 247, 6277-6279

Trentham, D. R. (1971) Biochem. J. 122, 71-77

Velick, S. F. \& Hayes, J. E. (1953) J. Biol. Chem. 203, 545-562

von Ellenrieder, G., Kirschner, K. \& Schuster, I. (1972) Eur. J. Biochem. 26, 220-236

Wrba, A., Schweiger, A., Schultes, V., Jaenicke, R. \& Závodszky, P. (1990) Biochemistry 29, 7584-7592

\title{
APPENDIX
}

\section{The preparation and properties of bromoacetylphosphonic acid}

Michael J. SPARKES and Henry B. F. DIXON

Department of Biochemistry, University of Cambridge, Tennis Court Road, Cambridge CB2 1QW, U.K.

\begin{abstract}
Bromoacetylphosphonic acid, $\mathrm{Br}-\mathrm{CH}_{2}-\mathrm{CO}-\mathrm{PO}_{3} \mathrm{H}_{2}$, was made by brominating dimethyl acetylphosphonate and deesterifying with $\mathrm{HBr}$. It proves to be a powerful alkylating agent, reacting rapidly with $\mathrm{GSH}$, with a rate constant of about $6 \mathrm{M}^{-1} \cdot \mathrm{s}^{-1}$ at $\mathrm{pH} 6$.
\end{abstract}

\section{INTRODUCTION}

Acetylphosphonic acid, $\mathrm{CH}_{3}-\mathrm{CO}-\mathrm{PO}_{3} \mathrm{H}_{2}$, can have biochemical uses as an analogue of pyruvate or of phosphate. Harrison, Perham and Slater (cited by Ambrose \& Perham, 1976) found it to be an effective inhibitor of pyruvate dehydrogenase, with a $K_{\text {. }}$ of $4 \mu \mathrm{M}$, and Kluger \& Pike (1977) reported that its monomethyl ester, which bears only a single charge at neutral $\mathrm{pH}$, is an even better inhibitor, with a $K_{1}$ of $0.05 \mu \mathrm{M}$. It therefore seemed of interest to make an alkylating derivative of this compound, so we developed a synthesis of bromoacetylphosphonic acid. This molecule, $\mathrm{Br}-\mathrm{CH}_{2}-\mathrm{CO}-\mathrm{PO}_{3} \mathrm{H}_{2}$, possesses two electrophilic centres, the activated bromomethyl group, expected to react preferentially with polarizable nucleophiles, and a carbonyl group, expected to be sensitive to basic nucleophiles (cf. Edwards, 1956). They are closer to the phosphono group than in the previously madebromoacetyl phosphate, $\mathrm{Br}-\mathrm{CH}_{2}-\mathrm{CO}-\mathrm{O}-\mathrm{PO}_{3} \mathrm{H}_{2}$.

\section{RESULTS}

The bromoacetylphosphonic acid was synthesized by treating dimethyl acetylphosphonate, $\mathrm{CH}_{3}-\mathrm{CO}-\mathrm{PO}(-\mathrm{O}-\mathrm{Me})_{2}$, with $\mathrm{Br}_{2}$, and completing the de-esterification with $\mathrm{HBr}$ in acetic acid. It proves to react rapidly with GSH, at about $6 \mathrm{M}^{-1} \cdot \mathrm{s}^{-1}$ at $\mathrm{pH} 6$.

\section{EXPERIMENTAL}

\section{Synthesis}

Dimethyl acetylphosphonate, $\mathrm{CH}_{3}-\mathrm{CO}-\mathrm{PO}(-\mathrm{O}-\mathrm{Me})_{2}$, was used as starting material, and was made by a modification of the method of Kabachnik \& Rossiǐskaya (1945), as follows. Acetyl chloride $(20 \mathrm{ml}, 0.28 \mathrm{~mol})$ was cooled to $0^{\circ} \mathrm{C}$. Trimethyl phosphite $(30 \mathrm{ml}, 0.25 \mathrm{~mol})$ was added slowly with stirring and cooling, and the mixture was then heated to $80^{\circ} \mathrm{C}$ for $5 \mathrm{~min}$ to drive off unchanged acetyl chloride. The crude product $(39.2 \mathrm{~g}$, $38 \mathrm{~g}$ theoretical) was used for bromination without purification. To a portion ( $38 \mathrm{~g}, 0.25 \mathrm{~mol}$ if pure) a few drops of $\mathrm{Br}_{2}$ were added and the mixture was warmed until decolorization started (about $\left.50^{\circ} \mathrm{C}\right)$. The rest of the $\mathrm{Br}_{2}(6.5 \mathrm{ml}, 0.125 \mathrm{~mol})$ was then added slowly with cooling to keep the temperature below $50^{\circ} \mathrm{C}$. Less than the theoretical quantity of $\mathrm{Br}_{2}$ was used to avoid formation of dibromoacetylphosphonic acid. After this, $40 \mathrm{ml}$ of $45 \% \mathrm{HBr}$ in acetic acid was added, and the mixture was kept at about $20^{\circ} \mathrm{C}$ overnight [Cooke et al. (1953) had similarly deesterified acetylphosphonic acid with anhydrous $\mathrm{HBr}$. The mixture was evaporated to dryness, and cooled with ice while it was dissolved in water and adjusted to $\mathrm{pH} 3.0$ with cyclohexylamine. The solution was again evaporated to dryness, and traces of water were removed by re-evaporation from ethanol. The solid formed was washed by suspending and filtering off, five times with ethanol and five times with methanol, to remove cyclohexylamine salts of $\mathrm{HBr}$, acetic acid and acetylphosphonic acid. A residue of $24.8 \mathrm{~g}$ remained (66\% based on the $\mathrm{Br}_{2}$ added, $34 \%$ on the trimethyl phosphite).

\section{Characterization}

On electrophoresis in $5 \%$ acetic acid $/ 0.5 \%$ pyridine, $\mathrm{pH} 3.5$, on Whatman $3 \mathrm{MM}$ paper cooled in white spirit, the product gave a single spot of 0.91 of the mobility of orthophosphate and 0.88 of the mobility of acetylphosphonic acid (with glucose as a standard of zero mobility) when stained for its carbonyl group by spraying with $5 \mathrm{~mm}$-2,4-dinitrophenylhydrazine in $2 \mathrm{M}-\mathrm{HCl}$, and for its ability to bind $\mathrm{Fe}^{3+}$ ions by spraying with $\mathrm{FeCl}_{3}$ and sulphosalicylic acid solutions (the phosphate test of Wade \& Morgan, 1953). [See Dixon \& Sparkes (1974) for details of paper electrophoresis and staining.]

The crude product was stirred in methanol $(50 \mathrm{ml}$ per $\mathrm{g})$ until dissolved; it crystallized on addition of diethyl ether. Elementary analysis gave $\mathrm{C}, 31.9 ; \mathrm{H}, 5.7 ; \mathrm{N}, 4.6 \% ; \mathrm{C}_{8} \mathrm{H}_{17} \mathrm{BrNO}_{4} \mathrm{P}$ requires $\mathrm{C}, 31.8 ; \mathrm{H}, 5.7 ; \mathrm{N}, 4.6 \%$. Titration in water gives a $\mathrm{pK}$ of 5.2 and a molar mass of $299 \mathrm{~g} / \mathrm{mol}$ (theoretical 302).

\section{Preparation of the lutidine salt}

Because of the difficulty of dissolving the cyclohexylamine salt, the salt with 2,6-lutidine was used for kinetic experiments. The cyclohexylamine salt was stirred with the sulphonic resin Zerolit $225 \mathrm{SRC} 13\left(\mathrm{H}^{+}\right.$form $)$in water, and the suspension was filtered through a small bed of the same resin to obtain a solution of the free acid. This was adjusted to $\mathrm{pH} 3$ with 2,6-lutidine, and was evaporated to dryness on a rotary evaporator. Ethanol was added and the solution again evaporated a few times until a 
crystalline solid remained. Recrystallization from a solvent was not achieved.

\section{Reaction with GSH}

Solutions of 4 mM-bromoacetylphosphonic acid as its lutidine salt and of $0.2 \mathrm{~mm}-\mathrm{GSH}$ were prepared, both adjusted to $\mathrm{pH} 6.0$ with 2,6-lutidine. Reaction mixtures were made up from these solutions as follows: $0.1 \mathrm{~mm}-\mathrm{GSH}$ in $2 \mathrm{~mm}-$ and $1 \mathrm{mM}-$ bromoacetylphosphonate, and $0.05 \mathrm{~mm}-\mathrm{GSH}$ in $0.5 \mathrm{~mm}$ bromoacetylphosphonate. Samples $(4 \mathrm{ml})$ were taken from these solutions at $1 \mathrm{~min}$ intervals, and assayed for thiol groups by addition to a mixture of $1 \mathrm{M}$-Tris/ $\mathrm{HCl}$ buffer, $\mathrm{pH} 8.4$, and $0.5 \mathrm{ml}$ of $5 \mathrm{~mm}$-5,5'-dithiobis-(2-nitrobenzoic acid) (Ellman's reagent), and measurement of absorbance at $410 \mathrm{~nm}$. A plot of the logarithm of this absorbance against time gave psuedo-firstorder rate constants of $0.59,0.36$ and $0.22 \mathrm{~min}^{-1}$ respectively, giving a second-order constant of about $6 \mathrm{M}^{-1} \cdot \mathrm{s}^{-1}$. This is over 100 times the value calculated for iodoacetamide at pH 6 from the $\mathrm{p} K$ of GSH and the value of $27 \mathrm{M}^{-1} \cdot \mathrm{s}^{-1}$ found by Halász \& Polgár (1976) at high $\mathrm{pH}$.

We thank many colleagues, especially Professor L. D. Byers and Professor K. Brocklehurst, for helpful advice and discussion.

\section{REFERENCES}

Ambrose, M. C. \& Perham, R. N. (1976) Biochem. J. 155, 429-432 Cooke, V. F., Gerrard, W. \& Green, W. J. (1953) Chem. Ind. (London) 351-352

Dixon, H. B. F. \& Sparkes, M. J. (1974) Biochem. J. 141, 715-719

Edwards, J. O. (1956) J. Am. Chem. Soc. 78, 1819-1820

Halász, P. \& Polgár, L. (1976) Eur. J. Biochem. 71, 563-569

Kabachnik, M. I. \& Rossiǐskaya, P. A. (1945) Izvest. Akad. Nauk SSSR Ser. Khim. 364-374

Kluger, R. \& Pike, D. C. (1977) J. Am. Chem. Soc. 99, 4504-4506

Wade H. E. \& Morgan D. M. (1953) Nature (London) 171, 529530

Received 4 October 1990/12 November 1990; accepted 14 November 1990 